\title{
Religious and cultural diversity and inclusive practice
}

\author{
Michael J Reiss
}

\section{Introduction}

A decade or two ago and many might have supposed that religion was increasingly becoming less important for schools in Britain. However, this has not proved to be the case. While personal religious belief and practice is unimportant for a growing number of people in Britain, there are many for whom it remains significant. Furthermore, the numbers for whom religion is personally relevant have been swelled both by immigration, including children born in such families, and by a tendency found in many religions in recent decades for some religious believers to have become more fundamentalist / literalist. In addition, religious matters now seem more evident in the public arena - whether we are talking about the wearing of religious dress (e.g. the burqa) or religious symbols (e.g. a cross), attitudes to gay marriage, the rise of militant atheism or religious terrorism. In education, the situation is complicated by new forms of faith schooling (Chapman et al. 2014, ParkerJenkins et al. 2014).

This chapter examines such issues from the perspective of teachers working in schools. The fundamental premise is that the right to hold a particular belief, religious or secular, should be accepted as part of a wider spectrum of rights to equal participation in education, regardless of difference - and this point applies to teachers as well as to students. Inclusive schools welcome the diversity represented by members of their neighborhood communities and regard differences as sources for enriching teaching and learning and for fostering harmonious, respectful relationships and mutual understanding (e.g. Mirza and Meetoo 2012). However, there are times when such well-intended sentiments are easier to state than to put into practice! This chapter both considers the fundamental issues at stake and suggests pragmatic ways forward for school leaders and classroom teachers.

The chapter title includes the phrase 'cultural diversity' to indicate that one way of seeing religion is as a part of culture. In one sense there is nothing specific to religion for a school dealing with issues of inclusion. By way of analogy (though analogies are always risky as some people treat them as if there were intended to be identities), having a religious faith is a bit like being a vegetarian. Some vegetarians believe passionately in the importance of vegetarianism and argue strongly that for anyone to eat meat is wrong - even murder (a PETA slogan as well as a hit album by The Smiths); other vegetarians, while equally passionate about not eating meat themselves, believe strongly in the right of others to eat meat if they so choose; still other vegetarians are more laid back about their own eating habits and not averse sometimes to eating fish and eggs. 


\section{The historical context in the UK}

It is widely known that until the introduction of the National Curriculum in 1988, religious education was the only subject that schools in England and Wales were required to teach. Less well known is that this requirement dates back to the 1870 Elementary Education Act. Furthermore, this Act stipulated that 'No religious catechism or religious formulary which is distinctive of any particular denomination shall be taught in the school' (Section 14). At the time, the presumption was that the education would be Christian (hence 'denomination' rather than 'religion') but thus began the long tradition, distinctive to England, that religious education was not to be a nurturing in the state religion (Barnes et al. 2012). This contrasts with the situation that obtains in most countries where state schools promulgate the official or majority state religion, though there are countries, notably France, Turkey and the USA, where no religious education takes place in state schools. Also included in the 1870 Act was the right, which persists to this day, of parents to remove their children from religious instruction (as the subject was then called).

The legal situation concerning religious education and associated matters (e.g. collective worship) in schools is quite complicated and fast moving and there are important differences among the four UK nations and among the various types of school. In particular, the law does now allow for certain state schools with a religious character to favour one religion over others. Nevertheless, the key features of a religious education in state schools - that it is a core part of the curriculum, has provision for student withdrawal, must be part of a broad and balanced curriculum and must have regard to community cohesion - means that the position of religious education in UK schools is often held to be a much healthier one than in many other countries. This is despite quite frequent calls that religious education be either abolished or made optional, perhaps to be replaced by lessons in philosophy, in citizenship or in personal, social and health education.

\section{The importance of religion to people}

For people for whom religion is important, it can be important in two main ways: for belief and for practice. World-wide, religion remains of significance to many people, including young people; a survey undertaken in 2011 in 24 countries found that $73 \%$ of respondents under the age of 35 (94\% in primarily Muslim countries and $66 \%$ in Christian majority countries) said that they had a religion / faith and that it was important to their lives (Ipsos MORI 2011; see also Smyth et al. 2013).

For some people, their religious faith is absolutely the core of their being: they could no more feel comfortable acting or thinking in a way that conflicted with their religious values than they could feel comfortable not eating. Other ways of expressing this are to say that their worldview is a religious one or that religion plays a central part in their identity. For other people, religious faith is either an irrelevancy - an historical anachronism - or positively harmful with 
many of the ills that befall humankind being placed at its door (Halstead and Reiss 2003).

It can be difficult for those who have never had a religious faith, or have only had one rather tenuously, to imagine what a life is like that is lived wholly within a religious ordering. Anthropologists provide good accounts of what it can be like to live a life where one's religious faith integrates with every aspect of one's life. One of my favourite such accounts is that of du Boulay (2009) who studied life in a Greek Orthodox Village in the late 1960s and early 1970s. Everything that happened in the village needs to be understood by reference to Greek Orthodoxy. To give just one instance, the annual liturgical and agricultural cycles intermeshed, so that after the harvest, the sowing of the seed for next year's harvest was closely related to the Christian calendar:

The main sowing of the wheat is carried into November, and the Archangel Michael, celebrated on 8 November and seen on his icons with drawn sword, is a formidable figure associated with the darkening November days with the leaves being stripped from the trees and the smoke gusting in ashy draughts down the chimneys; but this is a month

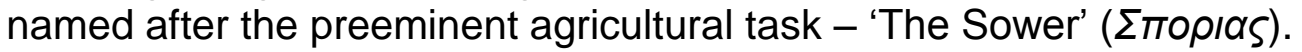
And the Entry of the Mother of God into the Temple on 21 November, soon after the Christmas fast has begun, is also in the village given the character of the time as the 'Mother of God Half-Way-Through-The-

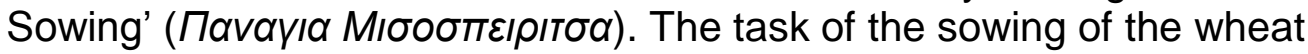
then continues into the time know as 'Andrew's' (St Andrew, whose day is 30 November, but who has given his name to the following month of December), and can go on up to Christmas - and even beyond, if the weather has not been fit (du Boulay 2009: 106).

Of course, having a secular or atheistic approach to life can be as important for some people as having a religious approach to life is for others. With the humanist John White I have argued that atheism should be studied in schools (Reiss and White 2009). Young people should think about whether they live in a divine world or a godless one. This points to discussing the standard arguments for and against the existence of God and such questions as the likelihood of life after death. They also need to discuss whether human lives can have any meaning or point outside a religious framework and whether people can live a morally good life that is not dependent on religious belief.

Sensitivity and respect are required when teaching about such matters. One does not want young people to be given the impression that they are going to hell because they espouse atheism or that they are intellectually second rate because they accept the divine inspiration of scripture.

\section{The particular place of religious education lessons}

The aims and content of religious education lessons have varied far more in recent decades than has been the case for many other subjects. When I think back to my own 1960s' and 1970s' schooling, my religious education was 
dire. We were fed a watered-down, bible-based and historical account of Christianity. With hindsight I think there was a vague hope that this might make us better people though the fare we were offered seemed more likely to put one off religion than attract or inspire one. (I recall regular homeworks where I learnt that week's Collect, and scripture, as it was called, was the one subject that I managed to come bottom in, $27^{\text {th }}$ out of 27 , in any school test or examination.)

The notion of confessional religious education - i.e. that teaching the subject might lead to the development or strengthening of religious faith - was abandoned in the 1970s, largely as a result of the publication by School Council (1971) of Working Paper 36: Religious Education in Secondary Schools. Two main arguments against confessional religion were advanced: first, that confessional education entails indoctrination; secondly that confessional education is inappropriate within an increasingly secular and pluralist society. The first argument has been controversial and there are those who continue to maintain that a confessional religion need not entail indoctrination, indeed that to abandon confessionalism is to submit to a form of liberal indoctrination that makes the implicit assumption that fostering any religious belief is educationally indefensible.

The second argument - that school religious education needs to take account of life in a diverse society where Christianity is much less central than it once was both because of a substantial increase in the number of people with no religious faith and because of increasing numbers of adherents of other faiths - is widely accepted (Barnes 2012). Religious education responded in a number of ways. Particularly popular was a 'world religions' approach. The expectation was that at the least students during their schooling would study what are often referred to as the six 'world religions' of Buddhism, Christianity, Hinduism, Islam, Judaism and Sikhism. Furthermore, the influential Qualifications and Curriculum Authority Non-Statutory National Framework recommended the study of further traditions 'such as the Bahá'i faith, Jainism and Zoroastrianism ... and secular philosophies such as humanism' (Qualifications and Curriculum Authority 2004: 12).

While well-meaning, this multi-faith approach ran into a number of difficulties. For a start, studying so many religions rarely inspired students, leading instead to shallow learning of miscellaneous facts (the five pillars of Islam, the five, eight or ten precepts of Buddhism, etc). Other objections were that such teaching failed to connect to students' needs, gave a false impression of religion by denying diversity within religions, created a divide between how religion is experienced by adherents and presented in the classroom, failed to engage students critically with religious truth claims and underplayed the historical and contemporary importance of Christianity in British society (Watson 2012).

More recent curricula have reduced the number of religions that are studied, placing more emphasis on those that are relevant to the students in a school and in the local communities from which they come. An additional feature of successful religious education curricula is that they contain a substantial 
amount of material on values and ethics. While ethics can be taught in many subjects, teachers of religious education often have particular expertise in this area. At a time when much of the school curriculum is often criticised for being fact-heavy, good teaching about ethics can be both popular and educationally valuable. It can introduce students to ways in which fundamental questions about human meaning and existence have been addressed while giving student considerable autonomy to develop their own thinking. There are, for example, no single, universally agreed 'right answers' to such questions as whether abortion is permissible, whether we have duties to the environment and if/when war is morally right.

\section{School-wide issues}

There are many issues to do with religion and inclusion that exist outside of religious education lessons. For a start it remains the case, for community schools in England and Wales, that the law states that a collective act of worship must take place daily and be wholly or mainly of a Christian character. This is a requirement far more honoured in the breach than in the observance. In their efforts not to offend students and to provide for assemblies that 'work' in school terms, few secondary schools other than faith schools nowadays provide true collective worship. In one school in which I worked, an enthusiastic group of students asked for, and received, permission to hold a half-termly alternative assembly, which was overtly Christian. (This was back in the 1980s in Cambridgeshire when few other religions were represented among the student body.) Initially about $10 \%$ of the students came to the alternative assembly. However, the students, nominally under my charge (I mainly tended to tone down the occasional over-enthusiastic suggestion for what might take place in the assembly), put so much time and thought into providing this alternative, often with humour, that it rapidly grew in popularity. Eventually, the majority of the students came to it and it had to be held in the main hall while the 'main' (secular) assembly was held in a smaller room. The highlight was a sketch based on the head-to-head duologue of Mel Smith and Griff Rhys Jones' Alas Smith and Jones about the real meaning of Christmas that brought the house down, receiving wave after wave of cheers.

More generally, the task of a school, whether of a religious nature or not, includes affirming in its ethos the value of diversity. This seems to me a key point in respect of the place of religion in a pluralist society. It is increasingly acknowledged that one cannot prove or disprove the validity or worth of religious faith. Given that both religious faith and atheism / secularism / agnosticism are widely represented in society, it is important that schools help students of all persuasions to live and work together respectively both now in school and in the future beyond school (cf. Starkey 2015).

This is not to imply that schools should accept every view about religion. Schools have a role to play in tackling extremism, including religious extremism. Savage (2013) has shown how education can move people from low to high integrative complexity. Integrative complexity is about how straightforwardly we understand issues. In everyday language, people with 
low integrative complexity see things as 'black or white' issues and this is more likely to be associated with violence. More generally, extremist

ideologies avoid complexity.

\section{Science education}

One place within schools where religion not infrequently rears its head outside of religious education lessons is in science. Issues to do with religion seem increasingly to be of importance in school science lessons. To many science educators even raising the possibility that religion might be considered within science education raises suspicions that this is an attempt to find a way of getting religion into the science classroom for religious rather than scientific reasons. This is not the intention here. Part of the argument is that considering religion can be, on occasions, useful simply for helping learners better understand why certain things come under the purview of science and others don't (Reiss 2014).

Another argument for considering religion within science education proceeds much as an argument for considering history in science education might. While science can be learnt and studied in an historical vacuum, there are a number of arguments in favour of examining science in its historical contexts. For a start, this helps one understand better why certain sorts of science were pursued at certain times. Wars, for instance, have sometimes led to advances in chemistry, physics and information science (e.g. explosives, missile trajectories, code breaking), while certain botanical disciplines, such as systematics and taxonomy, have flourished during periods of colonisation. Then there is the observation that for many learners understanding science in historical context can aid motivation.

Similarly, while many students enjoy learning about the pure science of genetics and evolution, otherwise are motivated and come to understand the science better if they appreciate something of the diversity of religious beliefs held by such principal protagonists as Charles Darwin, Joseph Hooker, Thomas Huxley and Gregor Mendel. Such teaching is enhanced if students come to appreciate the religious views (including the diversity of religious views) of the cultures in which such scientists lived and worked.

There are a number of places where religion and science interact. Consider, first, the question of 'authority' and the scriptures as a source of authority. To the great majority of religious believers, the scriptures of their religion (the Tanakh, the Christian bible, the Qur'an, the Vedas, including the Upanishads, the Guru Granth Sahib, the various collections in Buddhism, etc.) have an especial authority by very virtue of being scripture. This is completely different from the authority of science. Newton's Principia and Darwin's On the Origin of Species are wonderful books but they do not have any permanence other than that which derives from their success in explaining observable phenomena of the material world and enabling people to see the material world through Newtonian / Darwinian eyes. Indeed, as is well known, Darwin knew almost nothing of the mechanism of inheritance despite the whole of his 
argument relying on inheritance, so parts of The Origin were completely out of date over a hundred years ago.

Then consider the possibility of miracles, where the word is used not in its everyday sense (and the sense in which it is sometimes used in the Christian scriptures), namely 'remarkable', 'completely unexpected' or 'wonderful' (as in the tabloid heading 'My miracle baby'), but in its narrower meaning of 'contrary to the laws of nature'. Scientists who do not accept the occurrence of miracles can react to this latter notion of miracles in one of three ways: (i) miracles are impossible (because they are contrary to the laws of nature); (ii) miracles are outside of science (because they are contrary to the laws of nature); (iii) miracles are very rare events that haven't yet been incorporated within the body of science but will be (as rare meteorological events, e.g. eclipses, and mysterious creatures, e.g. farm animals with two heads or seven legs, have been).

The relationship between science and religion has changed over the years (Brooke 1991, Al-Hayani 2005); indeed, the use of the singular, 'relationship', risks giving the impression that there is only one way in which the two relate. Nevertheless, there are two key issues: one is to do with understandings of reality; the other to do with evidence and authority. Although it is always difficult to generalise, most religions hold that reality consists of more than the objective world and many religions give weight to personal and/or (depending on the religion) institutional authority in a way that science generally strives not to.

For example, there is a very large religious and theological literature on the world to come, i.e. life after death, (e.g. Hick 1976/1985). However, to labour the point, although some (notably Atkins 2011) have argued that science disproves the existence of life after death, it can be objected that science, strictly speaking, has little or nothing to say about this question because life after death exists or would exist outside of or beyond the realm to which science relates.

It is clear that there can be a number of axes on which the science/religion issue can be examined. For example, the effects of the practical and ritual dimension are being investigated by scientific studies that examine such things as the efficacy of prayer and the neurological consequences of meditation (e.g. Lee and Newberg 2005); a number of analyses of religious faith, informed by contemporary understandings of evolutionary psychology, behavioural ecology and sociobiology, examine the possibility or conclude that religious faith can be explained by science (e.g. Dennett 2006); the narrative/mythic dimension of religion clearly connects with scientific accounts of such matters as the origins of the cosmos and the evolution of life (Reiss 2011); the doctrinal and philosophical dimension can lead to understandings that may agree or disagree with standard scientific ones (e.g. about the status of the human embryo); and the ethical and legal dimension can lead to firm views about such matters as land ownership, usury and euthanasia. 


\section{Sex education}

Most of the world's religions have a great deal to say about sexual values. Of course, those with a religious faith also need to understand something of secular reasoning about sexual ethics: it is still too often the case that those with a religious faith assume that only they (a) really know what is good sexual behaviour; (b) can put such knowledge into effect.

In recent years there has been an increasing acknowledgement from all sex educators, whether or not they themselves are members of any particular religious faith, that religious points of view needs to be taken into account, if only because a significant number of children and their parents have moral values significantly informed by religious traditions.

The first major attempt in the UK among believers from a number of religious traditions to agree a religious perspective on sex education resulted in an agreed statement by members of six major UK religions (Islamic Academy 1991). This statement provided a critique of contemporary sex education, listed principles which it was felt ought to govern sex education and provided a moral framework for sex education. This framework 'Enjoins chastity and virginity before marriage and faithfulness and loyalty within marriage and prohibits extramarital sex and homosexual acts', 'Upholds the responsibilities and values of parenthood', 'Acknowledges that we owe a duty of respect and obedience to parents and have a responsibility to care for them in their old age and infirmity' and 'Affirms that the married relationship involves respect and love' (Islamic Academy 1991: 8).

Another early UK project to look at the important of religion and ethnicity for sex education was the Sex Education Forum's 'religion and ethnicity project'. A working group was set up which 'was concerned to challenge the view that religions offer only negative messages around sex, wanting to explore the broader philosophy and rationale behind specific religious prescriptions' (Thomson 1993: 2). Each participant was sent a total of 28 questions (e.g. 'Are there different natural roles for men and women, if so why?' and 'What is the religious attitude towards contraception and/or 'protection' for example, safe sex re: STDs, HIV?') and the project chose to present a range of views, rather than attempting to reach a consensus. The outcome was a pack that had chapters on Anglican, Hindu, Islamic, Jewish, Methodist, Roman Catholic, secular and Sikh perspectives.

At the same time as Rachel Thomson was compiling her pack, Gill Lenderyou and Mary Porter of the Family Planning Association were putting together a booklet arising from the 'Values, faith and sex education' project (Lenderyou and Porter 1994). At a four-day residential event in this project, a bill of pupils' rights was drawn up by 22 people of different religious faiths, and agreed statements on sex education were produced under the headings of: Respect and difference, Faith and change in society, Male and female equality, Relationships and marriages, Homosexuality, Cohabitation, Disability and sexuality, and Celibacy. The bill of pupils' rights is more liberal and the agreed statements are more tentative than the contents of Islamic Academy (1991). 
For example, included in the bill of pupils' rights are the assertions that pupils have the right to sex education that 'Provides full, accurate and objective information about growth and reproduction on topics including puberty, parenthood, contraception, child care and responsible parenthood' and that pupils have the right 'To be consulted about the manner in which sex education is implemented in the classroom in connection with issues such as whether it takes place in single sex or mixed groups or which topics can be included in the programme' (Lenderyou and Porter 1994: 37).

Subsequently, Shaikh Abdul Mabud and I edited an academic book titled Sex Education and Religion which concentrated on Christian and Muslim views about sex education (Reiss and Mabud 1998), and publications resulted from projects funded by the Department of Health's former Teenage Pregnancy Unit including 'Supporting the Development of SRE [sex and relationships education] within a Religious and Faith Context' (Blake and Katrak 2002). Since that time, an increasing of publications have considered the importance of religion for sex education (e.g. Rasmussen 2010, Smerecnik et al. 2010, Yip and Page 2013).

\section{Conclusions}

Schools are diverse communities yet UK schools have mostly been slow to consider religion as an inclusion issue. Done poorly, which it all too often is (Ofsted 2013), education about religion can bore students and achieve little. Done well - and not just through formal religious education lessons but in other subjects and in the life and ethos of the whole school - it can engage students, build knowledge, sharpen ethical thinking, contribute to community cohesion (Hess 2009, Woodward 2012) and make religious extremism less likely (Savage 2013).

However, this isn't always easy! In particular, teachers may find themselves holding very different views about the importance, relevance and messages of religion to those held by their students. There are various ways of dealing with this - schools typically have policies about such matters as religious dress and time for prayers. It is also important not to equate cultural practices concerning arranged marriages or female genital mutilation with religious positions. More generally, religion can be thought of as a controversial issue, namely as one where a range of positions may rationally be held. In most instances the cardinal rule is for teachers to respect students - and vice versa - even if they don't agree with them. As students grow older, they can benefit from teachers who disagree with them talking with them, helping them to think of the implications of their views, so long as this is always done in a nonconfrontational manner that doesn't appear to attack religion and doesn't abuse the authority that teachers have over their students.

\section{Reflection on values and practice}


- Should schools place any restrictions on the religious symbols or articles of clothing that students wear?

- Can sex education be positive about the teachings and practices of all religions?

- How can you manage an inclusive approach to religious diversity that takes account of your own views and those of your students?

- Is it realistic to expect schools to play a role in combatting religious extremism?

\section{Suggestions for further reading}

Barnes, L.P. (ed.) Debates in Religious Education, London: Routledge. Hess, D.E. (2009) Controversy in the Classroom, New York: Routledge. Mirza, H.S. and Meetoo, V. (2012) Respecting Difference: Race, Faith and Culture for Teacher Educators, London: IOE Press.

\section{References}

Al-Hayani, F.A. (2005) 'Islam and science: contradiction or concordance', Zygon, 40: 565-76.

Atkins, P. (2011) On Being: A Scientist's Exploration of the Great Questions of Existence, Oxford: Oxford University Press.

Barnes, L.P. (2012) 'Diversity', in Barnes, L.P. (ed.) Debates in Religious Education, London: Routledge, 65-76.

Barnes, L.P., Lundie, D., Armstrong, D., McKinney, S. and Williams, K. (2012) 'Religious education in the United Kingdom and Ireland', in Barnes, L.P. (ed.) Debates in Religious Education, London: Routledge, 22-51.

Blake, S. and Katrak, Z. (2002) Faith, Values and Sex \& Relationships Education, London: National Children's Bureau.

du Boulay, J. (2009) Cosmos, Life, and Liturgy in a Greek Orthodox Village, Limni, Evia: Denise Harvey.

Brooke, J.H. (1991) Science and Religion: Some Historical Perspectives, Cambridge: Cambridge University Press.

Chapman, J.D., McNamara, S., Reiss, M.J. and Waghid, Y. (eds) (2014) International Handbook of Learning, Teaching and Leading in Faith-Based Schools, Dordrecht: Springer.

Dennett, D.C. (2006) Breaking the Spell: Religion as a Natural Phenomenon, London: Allen Lane.

Halstead, J.M. and Reiss, M.J. (2003) Values in Sex Education: From Principles to Practice, London: RoutledgeFalmer.

Hess, D.E. (2009) Controversy in the Classroom, New York: Routledge.

Hick, J. (1976/1985) Death and Eternal Life, Basingstoke: Macmillan.

Ipsos MORI (2011) Religion and Globalisation, London: Ipsos MORI.

Islamic Academy (1991) Sex Education in the School Curriculum: The Religious Perspective - an agreed statement, Cambridge: Islamic Academy. 
Lee, B.Y. and Newberg, A.B. (2005) 'Religion and health: a review and critical analysis', Zygon, 40: 443-68.

Lenderyou, G. and Porter, M. (eds) (1994) Sex Education, Values and Morality, London: Health Education Authority.

Mirza, H.S. and Meetoo, V. (2012) Respecting Difference: Race, Faith and Culture for Teacher Educators, London: IOE Press.

Ofsted (2013) Religious Education: Realising the Potential, Manchester: Ofsted.

Parker-Jenkins, M., Glenn, M. and Janmaat, J.G. (2014) Reaching In, Reaching Out: Faith Schools, Community Engagement, and 21st-century Skills for Intercultural Understanding, London: IOE Press.

Qualifications and Curriculum Authority (2004) Religious Education: NonStatutory National Framework, London: QCA.

Rasmussen, M.L. (2010) 'Secularism, religion and 'progressive' sex education', Sexualities, 13: 699-712.

Reiss, M.J. (2011) 'How should creationism and intelligent design be dealt with in the classroom?', Journal of Philosophy of Education, 45: 399-415.

Reiss, M.J. (2014) 'What significance does Christianity have for science education?', in Matthews, M.R. (ed.) Handbook of Historical and Philosophical Research in Science Education, Dordrecht: Springer, 163762.

Reiss, M.J. and Mabud, S.A. (eds) (1998) Sex Education and Religion, Cambridge: Islamic Academy.

Reiss, M. and White, J. (2009) 'Atheism needs to be studied in schools', The Independent, Education, 16 July: 4.

Savage, S. (2013) 'Head and heart in preventing religious radicalization', in Watts, F. and Dumbreck, G. (eds) Head and Heart: Perpsectives from Religion and Psychology, West Conshohocken, PA: Templeton Press, 15793.

Schools Council (1971) Working Paper 36: Religious Education in Secondary Schools, London: Evans/Methuen.

Smerecnik, C., Schaalma, H., Gerjo, K., Meijer, S. and Poelman, J. (2010) 'An exploratory study of Muslim adolescents' views on sexuality: implications for sex education and prevention', BMC Public Health, 10: 533.

Smyth E., Lyons, M. and Darmody, M. (eds) (2013) Religious Education in a Multicultural Europe, Basingstoke: Palgrave Macmillan.

Starkey, H. (2015) Learning to Live Together: Struggles for Citizenship and Human Rights Education, London: IOE Press.

Thomson, R. (ed.) (1993) Religion, Ethnicity \& Sex Education: Exploring the Issues - a resource for teachers and others working with young people, London: National Children's Bureau.

Watson, B. (2012) 'Why religious education matters, in Barnes, L.P. (ed.) Debates in Religious Education, London: Routledge, 14-21.

Woodward, R. (2012) 'Community cohesion, in Barnes, L.P. (ed.) Debates in Religious Education, London: Routledge, 132-45.

Yip, A.K.-T. and Page, S.-J. (eds) (2013) Religious and Sexual Identities: A Multi-faith Exploration of Young Adults, Farnham: Ashgate. 